\title{
Ornamental Variety Of Bugis Houses In Aha Village
}

\author{
Hartati Kapita \\ Faculty of Engineering, Morotai University, Indonesia \\ Hartatia.albub@gmail.com
}

\begin{abstract}
The traditional house is a work that grows and develops under the influence of tradition, social activities, culture, and community behavior in a nation, and is part of the identity of a community. This study aims to find decorative patterns, meanings, and efforts to preserve traditional architecture on Morotai Island. Particularly in the settlement of the Bugis village of Aha village, the existence of Aha village has existed since 1950; the type of research is a qualitative research study using an observation and interview approach with the sampling technique carried out by purposive sampling. The results of the study show that in terms of living residents the community still adopts traditional Bugis architecture. Where can be seen from the shape of the house and all the procedures for its construction? In terms of material using local materials that are friendly to the environment. The existence of this Bugis house should be preserved because it has philosophical values. The Bugis tribe is a traditional house that has various decorations in various building elements as an aesthetic expression and has a philosophical meaning.
\end{abstract}

Keywords: Traditional Architecture, Aesthetics, Ornament, Traditional Houses, Buginese Tribes

\section{INTRODUCTION}

The traditional house is a work that grows and develops under the influence of the tradition of social culture activity and community behavior in a nation and is part of the identity of a community[1]. Traditional house are buildings with structures, procedure for making and ornament that have their own characteristic and are passed down from generation to generation[2]. Therefore, traditional Bugis house is supposed to be a reflection of a culture that has meaning and function. It was seen in the traditional house of Aha village that has become the identity of the Bugis tribe in the Pulau Morotai Regency as an asset that deserves its existence amid the glitter of modernization. The characteristic of the Bugis house is the house stage.in academic society needs to be conducted and intensified to cope with those problems.

House on stilts is an architectural product that is built without architects, and is one of the innovative formsoft natural environment, even material to the structure is also taken from the surrounding environment[3] as well as the stilt house in Aha village built without using architects and material $\mathrm{s}$ taken in the local environment.

The Bugis House in the Aha village is an existing settlement since 1950. The community citizens still adopt traditional Bugis architecture, where can be seen from the shape of the 
house and all the procedures for its construction. The material is still using environmentally friendly local materials. The existence of this Bugis house should be preserved because it has philosophical values.

Vitruvius says that three important elements had to be the basis of architecture, namely comfort, robustness, and beauty. The beauty of the building is usually used in an ornament. To know the ledge of the building can be seen from the shape of the variety. Decorative variety is a character in the establishment of self-development [4] That the ornamental variety is used as a symbolic meal of prosperity and safety[5]. Ornaments arise because it is inspired by two factors namely technique factor, and emotion factor, the technique factor in ornament related to the stamp or the object is made and how making it a sedation of emotion factor is the copyrighted result of belief, religion and magical[6]. The presence of an ornament in midst of human life since prehistoric times until now is not only expressed as an ornamental object, but in it also contain values, norms, and customs in accordance with the view of the supporting community, ornament are presented as markers or in the form of symbols that want to express something[7] Ornamental variety is a style of building that has symbolic meaning and is influenced by belief, emotion, religion, norm and customs than exist in society

\section{METHOD}

This research conducted at the Aha village of Pulau Morotai Regency. This research used the method of the analytical descriptions to obtain an idea of the reality of the object by describing the decorative components of the Bugis traditional house. This research using synchronous and diachronically analysis to study the ornaments of Bugis people in Aha village in the building façade. A further interpretation is done to give meaning to various forms of ornamental and function. The Data were gathered through interviews, literature, and observation.

\section{RESULT AND DISCUSSION}

In general, the traditional House of Bugis has a variety of ornaments or ornaments in some elements of the building as an aesthetic expression and has meaning. The use of decorative variations or ornaments on the work of architecture has been done for a long time as in the classical era. The selection and use of the ornaments at the time had a function as part of a building that has its value and meaning in architecture, especially seen in an aesthetic and decorative facet that gives the impression and character itself On the building[8]. The uses of decorative varieties or ornaments are usually tucked into a separate message and also have a cultural background that existed at the time.

Traditional ornaments can be applied as decorative and constructive elements in the design world. The application of decorative variety is often experienced change and development in terms of shape, pattern, material, manufacture and color techniques. In its development, decorative applications must be preserved the traditional meaning contained in it. This avoids the misuse of decorative ornaments that do not fit into place, so it has a different and wrong meaning[9] In addition to beautiflying the building ornament also have different according to the placement and meaning of the philosophy contained in the variety of ornament used[10]

Ornamental variety in the building is a complementary element of a home that serves to add aesthetic/beauty value.The process of interpreting Bugis house ornaments is generally based on the level of the building structure [11]. The ornamental function is to add aesthetic value to the building. The variety of decoration in the house of the Bugis tribe is different 
from the variety of Bugis ethnic ornaments in general that are identical with the form of flora and fauna. Each symbol that is in the decoration of each building has its function and meaning

\subsection{A Variety Of Ornamental on The Head Building}

In the traditional architectural philosophy, there is often a depiction of building roofs as a reflection of the human head and has a major role in life, likewise with buildings. While on the roof, it is the most important element in the design of a building. Head of the building in Aha village there are three decorative motifs

1. Fan Motif

In the traditional house of the Bugis tribe in Aha village found decorative fan-shaped. Homeowners believe that fans can bring sustenance to homeowners. There are seven numbers of nets on a well-meaning fan; where homeowners believe that the creator likes odd numbers so that homeowner is always sheltered by good things.

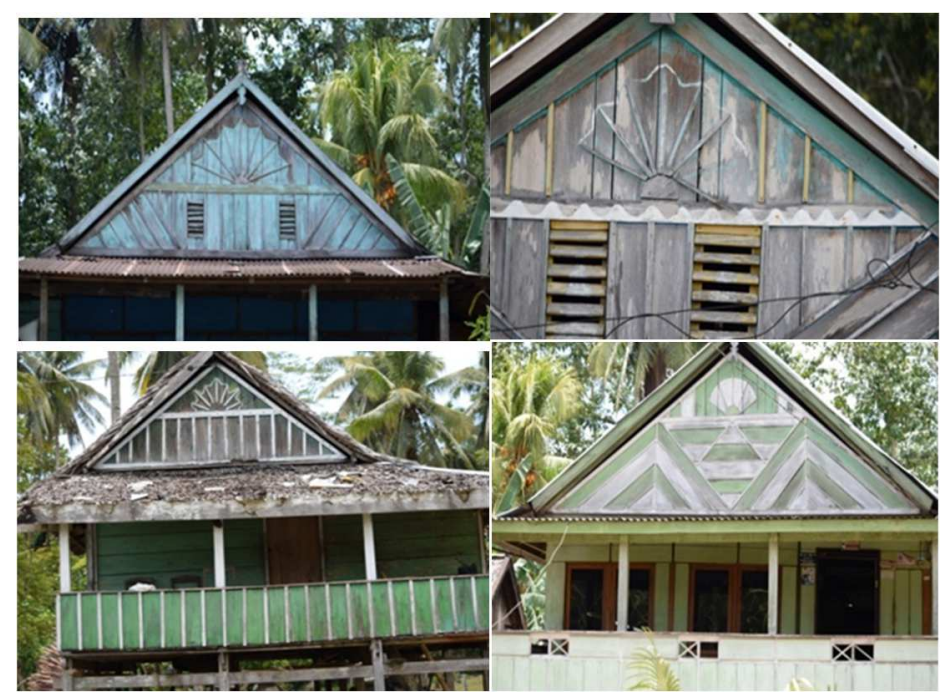

Figure 1 Fun Motif

2. The Sun Motif

In addition to the fan, there are also sun motifs on some buildings. The use of solar motifs means that the house dwellers are always enlightened and obtain abundant sustenance. The sun is the source of life that gives warmth to the universe

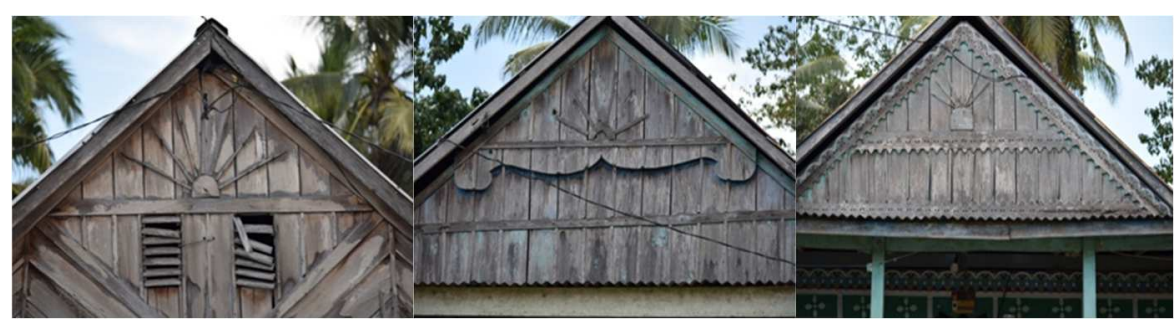




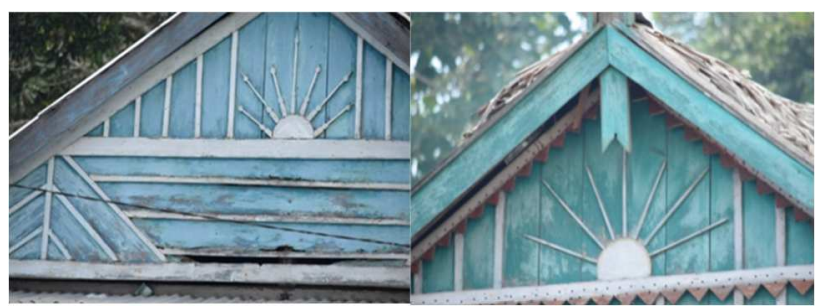

Figure 2 Sun Motif

3. Pattern Geometric

There is a geometric motif that is a repetition of a triangular shape and a repetition of a half-circle shape that is used in several buildings. The representing of a geometric shape is to add aesthetics to the building

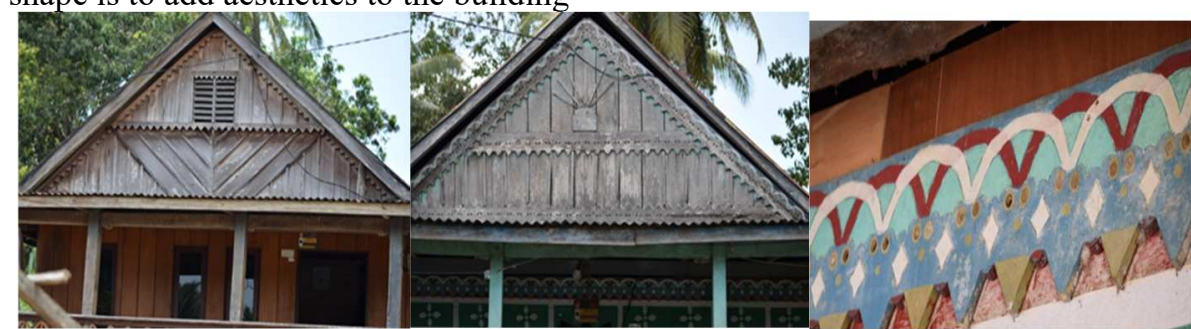

Figure 3. Geometric motifts

\subsection{A Variety of Ornamental Crowns on The Roof}

A decorative motif that is found on the crown of the roof or the Bugis community called it Anjong(the pinnacle), the motif is encountered is a pattern of a rooster that means as a symbol of strength, courage and patience homeowner. The purpose of wearing decorative variations on the Anjongintends for the homeowner to obtain the blessing of the deity or the ancestors.

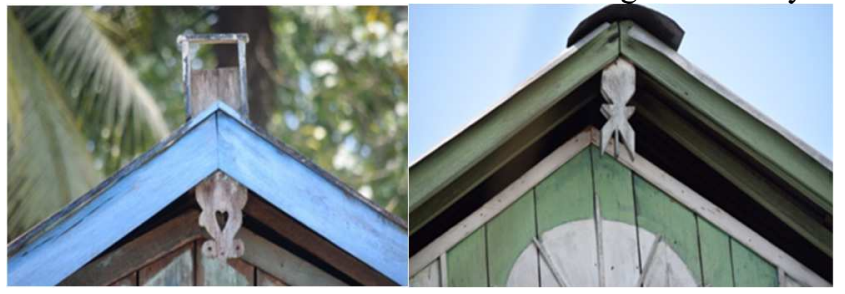

Figure 4. Rooster Motift

\subsection{A Variety of OrnamentalBody of The Building}

There are floral motifs on the walls inspired by the plants around the settlement. The purpose of this decorative range is to add aesthetic value to the building so that the residents feel comfortable and home. 


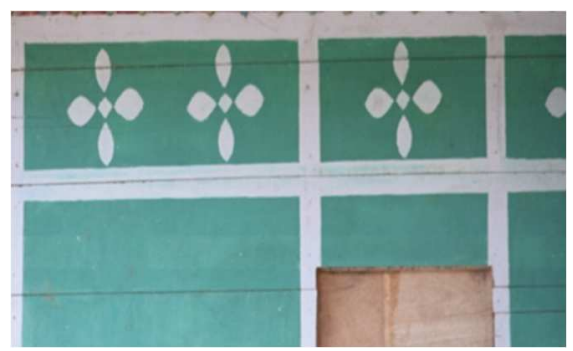

Figure 5 Floral Motift

Overall, the main function of the ornament is to decorate the building to add an aesthetic impression to make it more attractive to look at. Furthermore, in some traditional societies the use of ornament contains symbolic meaning with a specific purpose related to the philosophy of life of a society. Likewise with the ornament in the Aha Village, some do not have philosophical meaning and only as an aesthetic element, but some use ornament on the building which has to do with the philosophy of life.

\section{CONCLUSION}

The decoration is not just an aesthetic expression but has a philosophical meaning that has been believed to be hereditary. In the Aha village, there are four forms of decoration on the Bugis tribal houses, which are fan shape, sun shape, geometric shapes, and plant motifs. Pads of traditional architectural decoration are most often found on the head of a building; where the ancient ancestors believed that the top part of the building is a symbol of the upper world which is related to belief in the creator or ancestor that means very sacred.

\section{REFERENCES}

[1] E. Budiharjo, Rumah sebagai Warisan Budaya. Jakarta: Djambatan, 1997.

[2] Musdaria, "Prinsip-Prinsip Rumah Tradisional Bugis Dan Aplikasinya Terhadap Rumah Tanggap Banjir Di Makassar," Pros. Semin. Arch. IPLBI, pp. 92-100, 2018.

[3] B. Syarif, "Arsitek Arsitektur Tradisional Bugis," Enginering, vol. 12, no. 2, 2009.

[4] Amiuza, "Tipologi Rumah Tinggal Administrasi P.G. Kebon Agung di Kab Malang," Ruas, vol. IV, no. 1, pp. 1-22, 2006.

[5] Y. Sumalyo, Arsitektur Klasik Eropa. Yogyakarta: Gadjah Mada University Press, 2003.

[6] D. Soekiman, Kebudayaan Indis dan Gaya Hidup Masyarakt Pendukungnya di Jawa (Abad XVIII-Medio Abad XX). Yogyakarta: Yayasan Bentang Budaya, 2000.

[7] M. Patriansyah and Y. Hariansyah, "Kajian Fungsi Ornamen Rumah Tradisional Kampung Arab Al-Munawwar," Inject (Interdisciplinary J. Commun., vol. 3, no. 1, p. 83, 2018.

[8] B. Supriyadi (Pipiek), "Kajian Ornamen Pada Mesjid Bersejarah Kawasan Pantura Jawa Tengah,” J. Ilm. Peranc. Kota dan Permukim., vol. 7, no. 2, pp. 106-121, 2008.

[9] G. Hartanti and A. Nediari, "SEBAGAI UPAYA KONSERVASI BUDAYA BANGSA KHUSUSNYA PADA PERANCANGAN INTERIOR HASIL DAN PEMBAHASAN Provinsi Bali," Humaniora, vol. 5, no. 1, pp. 521-540, 2014.

[10] N. Qomariyyah and E. Yunitatitisari, "Ornamen Rumah Tinggal di Kampung Kemasan Gresik," Arsit. E- J., vol. 2, no. 2, pp. 79-89, 2009.

[11] P. P. Yunus, "Makna Simbol Bentuk Dan Seni Hias Pada Rumah Bugis Sulawesi 
Selatan ( The meaning of Symbol and Ornament forms on Bugis House in South Sulawesi)," J. Seni Budaya Panggung, vol. 22, no. 3, pp. 267-282, 2012. 